Org Lett. 2019 July 19; 21(14): 5685-5688. doi:10.1021/acs.orglett.9b02021.

\title{
Acyl Selenyl Sulfides as the Precursors for Reactive Sulfur Species (Hydrogen Sulfide, Polysulfide, and Selenyl Sulfide)
}

\author{
Akil Hamsath ${ }^{\dagger}$, Yingying Wang ${ }^{\dagger}$, Chun-tao Yang ${ }^{\dagger, \ddagger}$, Shi $\mathrm{Xu}^{\dagger}$, Danica Cañedo ${ }^{\dagger}$, Wei Chen ${ }^{\dagger}$, \\ Ming Xian ${ }^{*}, \dagger$ \\ †Department of Chemistry, Washington State University, Pullman, Washington 99164, United \\ States \\ ¥Affiliated Cancer Hospital \& Institute of Guangzhou Medical University, Guangzhou 510095, \\ China
}

\begin{abstract}
Persulfides are receiving increased attention due to their links to hydrogen sulfide $\left(\mathrm{H}_{2} \mathrm{~S}\right)$ and hydrogen polysulfide $\left(\mathrm{H}_{2} \mathrm{~S}_{\mathrm{n}}\right)$. Their close analogues selenyl sulfides (RSeSHs), however, have limited literature precedent, and their reactivity and possible role in biology are largely unknown. Here, we devised an acyl selenyl sulfide template to study RSeSH chemistry. Their stability and reactivity toward amines/thiols were studied. These compounds can produce $\mathrm{H}_{2} \mathrm{~S}$ or $\mathrm{H}_{2} \mathrm{~S}_{2}$ under different conditions, suggesting that RSeSHs are possible intermediates.
\end{abstract}

\section{Graphical Abstract}

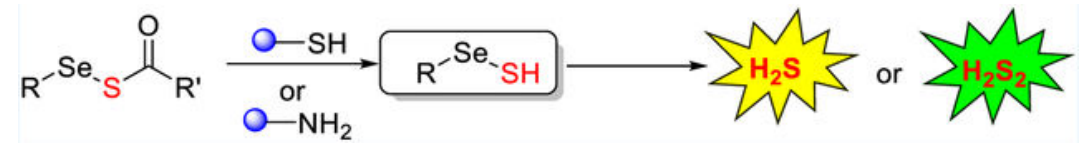

Reactive sulfur species (RSS) are a series of sulfur- containing molecules that play regulatory roles in biological systems. Recent studies have revealed that hydrogen sulfide $\left(\mathrm{H}_{2} \mathrm{~S}\right)$, persulfides (RSSHs), and hydrogen polysulfides $\left(\mathrm{H}_{2} \mathrm{~S}_{\mathrm{n}}, \mathrm{n} \geq 2\right)$ are perhaps the most interesting RSS, and they exhibit functions such as inducing S-perthiolation in many proteins. ${ }^{1,2}$ These molecules, in particular $\mathrm{RSSH}$ and $\mathrm{H}_{2} \mathrm{~S}_{\mathrm{n}}$, are highly reactive and unstable, which makes their research quite challenging. As such, much research effort has been put into developing chemical tools for delivering and detecting such RSS. ${ }^{3}$ Although significant progress in understanding RSSH has been made, their close analogues, selenyl sulfide (RSeSHs), are still largely unexplored. Selenocysteine ( $\mathrm{Sec}$ ) is the 21 st proteinogenic amino acid, and many selenoproteins are redox enzymes. Cys and Sec have many similar properties but only minor differences in terms of electronegativity, ionic radius, and available oxidation

\footnotetext{
*Corresponding Author: Tel: 509-335-6073. mxian@wsu.edu.

Supporting Information

The Supporting Information is available free of charge on the ACS Publications website at DOI: 10.1021/acs.or-glett.9b02021.

Experimental procedures and characterization of each compound (PDF)

The authors declare no competing financial interest.
} 
states. ${ }^{4}$ It is worth noting that the $\mathrm{pK}_{\mathrm{a}}$ of the selenol group ( $\left.\sim 5.3\right)$ in $\mathrm{Sec}$ is much lower than the thiol in Cys ( 8.3) and Sec has a lower redox potential than Cys ( -381 vs $-180 \mathrm{mV})$. These facts indicate that $\mathrm{Sec}$ is mostly deprotonated at physiological $\mathrm{pH}$ and very sensitive to redox regulation. The involvement of Sec in sulfur-related redox signaling is an interesting research topic. It is expected that Sec can readily react with certain reactive sulfur species to form selenyl sulfide (RSeSH), analogous to RSSH formation, though this has not been validated. A number of other questions about RSeSH remain unanswered, such as what their intracellular targets are and to what extent such reactions can impact signaling. A better understanding of RSeSH chemistry is needed to address these questions. It should be noted that the chemistry and properties of RSeSH are largely unknown in literature, except for a few theoretical studies. ${ }^{5}$ In our previous works, we used acyl disulfides (1) and 9-

fluorenylmethyl (Fm) disulfides (2) as the precursors for RSSH (Scheme 1), which could further produce $\mathrm{H}_{2} \mathrm{~S}$ in the presence of thiols like cysteine. ${ }^{6}$ We also found that cyclic acyl selenyl sulfide (3) could serve as a precursor for $\mathrm{RSeSH}$, which could also produce $\mathrm{H}_{2} \mathrm{~S}$ in the presence of cysteine. ${ }^{7}$ Analogously, we envisioned that acyclic acyl selenyl sulfides (4) could serve as the precursors of RSeSH, and this would be a general method for the access of RSeSH and be used to explore their chemistry. Herein, we report the preparation of acyclic acyl selenyl sulfides and their reactions with nucleophiles (amine/thiol). Their production of $\mathrm{H}_{2} \mathrm{~S}$ and $\mathrm{H}_{2} \mathrm{~S}_{2}$ under different treatments are also reported.

In the 1980s, acyclic acyl selenyl sulfides were studied as reagents to introduce seleno functionality into organic molecules. ${ }^{8}$ These compounds were synthesized by reacting selenyl thioates with $m$-CPBA or reacting selenyl phthalimides with thioacids. ${ }^{8}$ However, these methods rely on multistep operations and often yield many byproducts that make isolation and purification difficult. Here, we developed a simple method for synthesizing acyl selenyl sulfides under mild, one-pot conditions (Scheme 2). Briefly, selenyl chlorides 6 were generated upon the reaction between diselenide and $\mathrm{SO}_{2} \mathrm{Cl}_{2}$ and subsequently treated with thioacids to produce the desired acyl selenyl sulfides 7 in moderate to good yields. Overall, five substrates (7a-7e) were prepared and studied.

With these compounds in hand, we first tested their stability. Acyl selenyl sulfides were found to be reasonably stable in organic solvents like $\mathrm{CH}_{2} \mathrm{Cl}_{2}$ (dry, degassed, in dark). When their solutions were exposed to air and light, decomposition was noticed with the formation of diphenyl diselenide 5 and acyl disulfide 8 (Scheme 3a). This was likely due to a radical process. ${ }^{9}$ When these compounds were exposed to aqueous buffers, slow but immediate decomposition was observed. We also noticed that the process was $\mathrm{pH}$ dependent as they decomposed faster under basic conditions than under acidic conditions (Figure S1).

Diphenyl diselenide and elemental sulfur $\mathrm{S}_{8}$ were identified to be the products. As such, a hydrolysis mechanism was proposed (Scheme $3 b$ ), with the generation of selenyl sulfide 9 as the intermediate and eventually producing 5 and $\mathrm{H}_{2} \mathrm{~S}_{2}$ (which further degraded to $\mathrm{S}_{8}$ ). It should be noted that in these decomposition processes we did not observe the formation of $\mathrm{H}_{2} \mathrm{~S}$.

Given the structural similarity of acyl selenyl sulfides and acyl disulfides, we hypothesized that compounds 7 could serve as $\mathrm{H}_{2} \mathrm{~S}$-releasing agents in the presence of cysteine. Therefore, we tested their $\mathrm{H}_{2} \mathrm{~S}$-releasing ability in PBS buffers under the treatment of 
cysteine. The produced $\mathrm{H}_{2} \mathrm{~S}$ was measured using a $\mathrm{H}_{2} \mathrm{~S}$ gas trapping experiment. ${ }^{10}$ The results are shown in Figure 1. We expected that the change of acyl substitutions could affect the rates of thioester exchange with cysteine and regulate $\mathrm{H}_{2} \mathrm{~S}$ generation. Indeed, 7a showed the highest $\mathrm{H}_{2} \mathrm{~S}$ production (79\%), while more hindered substrates $7 \mathrm{~b}$ and $7 \mathrm{c}$ showed much decreased $\mathrm{H}_{2} \mathrm{~S}$ production ( $\sim 40 \%$ ). The alkyl selenide based substrate $7 \mathrm{e}$ also showed good $\mathrm{H}_{2} \mathrm{~S}$ production. These results demonstrated that $\mathrm{H}_{2} \mathrm{~S}$ release from these compounds could be regulated via structural modifications and the relative amounts of $\mathrm{H}_{2} \mathrm{~S}$ released could give access to researching the effects of different $\mathrm{H}_{2} \mathrm{~S}$ concentrations as they pertain to $\mathrm{Se}-\mathrm{S}$ redox regulations.

To understand the mechanism of $\mathrm{H}_{2} \mathrm{~S}$ release from these compounds, we analyzed the reaction products of $7 \mathrm{a}$ and cysteine ( 5 equiv). Cystine, $\mathrm{N}$-acetylcysteine, and diselenide 5 were found to be the products (Scheme $4 \mathrm{a}$ ). In addition, the reaction was completed within $15 \mathrm{~min}$. This indicated that the slow decomposition of $7 \mathrm{a}$ will not compete with its ability to release $\mathrm{H}_{2} \mathrm{~S}$ in the presence of cysteine. Although we were able to identify the products in this reaction, the nucleophilic residues of cysteine $\left(-\mathrm{SH}\right.$ and $\left.-\mathrm{NH}_{2}\right)$ could theoretically react with two possible electrophilic sites of $7 \mathrm{a}$ and both could lead to the formation of these products (vide infra). To better probe the mechanism, we decided to use simplified models to understand the reaction.

Benzylmercaptan $(\mathrm{BnSH})$ and benzylamine $\left(\mathrm{BnNH}_{2}\right)$ were used to test the difference in reactivity between the two electrophilic sites on 7a. As shown in Scheme 4b, BnSH preferentially reacted with the selenium on $7 \mathrm{a}$ (to produce 10 as the major product), while $\mathrm{BnNH}_{2}$ reacted only with the carbonyl to give 12 in almost quantitative yield. This type of reactivity is not surprising because thiols preferentially reacting with selenides over sulfides are known. ${ }^{11}$ We also carried out a competition reaction with equal amounts of $\mathrm{BnSH}$ and $\mathrm{BnNH}_{2}$ (Scheme 4c)and observed the formation of amide 12, diphenyl diselenide 5, benzyl disulfide 13, and selenyl sulfide 10. Based on these results, we proposed the mechanism of the reaction between $7 \mathrm{a}$ and cysteine as follows (Scheme 5): the reaction is initiated by a nucleophilic attack on the carbonyl by $-\mathrm{NH}_{2}$ of cysteine resulting in the selenyl sulfide intermediate $(\mathrm{PhSeSH})$. We have previously reported the presence of such an intermediate in cyclic acyl selenyl sulfides through similar reaction conditions. ${ }^{7}$ From this intermediate two pathways can contribute to $\mathrm{H}_{2} \mathrm{~S}$ release: (a) a nucleophilic attack on the selenide by the $\mathrm{SH}$ of cysteine to liberate $\mathrm{H}_{2} \mathrm{~S}$ and selenyl sulfide 14 , which further reacts with cysteine to produce cystine, and (b) a sulfide transfer with cysteine to form cysteine persulfide 15 and $\mathrm{PhSeH}$. Persulfide 15 further reacts with cysteine to form cystine and release $\mathrm{H}_{2} \mathrm{~S}$. $\mathrm{PhSeH}$ generated in both pathways can be oxidized to form $\mathrm{PhSeSePh}$.

Apart from $\mathrm{H}_{2} \mathrm{~S}$, hydrogen persulfide $\left(\mathrm{H}_{2} \mathrm{~S}_{2}\right)$ is believed to be another important signaling molecule, and its regulatory roles have been recently recognized. ${ }^{12}$ The unique structure of the selenyl sulfide (RSeSH) intermediate made us suspect compounds 7 could also serve as $\mathrm{H}_{2} \mathrm{~S}_{2}$ donors. We hypothesized that the RSeSH intermediate generated by the reaction of 7 and amines could degrade into diphenyl diselenide and $\mathrm{H}_{2} \mathrm{~S}_{2}$. To test this hypothesis, a $\mathrm{H}_{2} \mathrm{~S}_{2}$-specific fluorescent probe DSP- $3^{13}$ was used to monitor the reaction between $7 \mathrm{a}$ and butylamine. As shown in Figure 2, time- and concentration-dependent fluorescence increases were ob- served. We also used nitrofluorobenzoylate to trap in situ generated $\mathrm{H}_{2} \mathrm{~S}_{2}$ 
(Scheme 6), and the desired product 16 was obtained in $22 \%$ yield. These results demonstrated the formation of $\mathrm{H}_{2} \mathrm{~S}_{2}$ from the degradation of the RSeSH intermediate. Again, we did not observe $\mathrm{H}_{2} \mathrm{~S}$ formation in the reaction of 7a with butylamine.

Since donors like 7a have demonstrated their ability to release both $\mathrm{H}_{2} \mathrm{~S}$ and $\mathrm{H}_{2} \mathrm{~S}_{2}$ we wondered if they could release these sulfur species when interacting with cells. Cell-imaging experiments were then conducted to address this question. As shown in Figure 3, H9c2 cells were first loaded with a selective fluorescent probe for $\mathrm{H}_{2} \mathrm{~S}$ (WSP5 ${ }^{14}$ ) or $\mathrm{H}_{2} \mathrm{~S}_{\mathrm{n}}$ (DSP-3) and then treated with 7a. Donor-treated cells showed much enhanced fluorescent signals with the $\mathrm{H}_{2} \mathrm{~S}$ probe. However, we did not observe much fluorescence enhancement with the $\mathrm{H}_{2} \mathrm{~S}_{2}$ probe (data not shown). These results suggest that $\mathrm{H}_{2} \mathrm{~S}_{2}$ production from the donors was favored, presumably due to the presence of cellular thiols like cysteine. While the donors could also produce $\mathrm{H}_{2} \mathrm{~S}_{2}$ in theory, such a pathway might be minor, and the instability of $\mathrm{H}_{2} \mathrm{~S}_{2}$ might also contribute to its lack of detection.

In summary, this work demonstrated that acyl selenyl sulfides could serve as the precursors for $\mathrm{H}_{2} \mathrm{~S}$ and $\mathrm{H}_{2} \mathrm{~S}_{2}$, depending on the reaction conditions. Hydrolysis of acyl selenyl sulfides and their reactions with amine-based nucleophiles mainly lead to the formation of $\mathrm{H}_{2} \mathrm{~S}_{2}$, while the reaction with thiols (such as cysteine) lead to $\mathrm{H}_{2} \mathrm{~S}$ generation. Selenyl sulfides are likely the key intermediates. RSeSHs are expected to be important regulating molecules involved in Sec- related redox signaling. Acyl selenyl sulfides should be useful tools for better understanding the chemical biology of RSeSH.

\section{Supplementary Material}

Refer to Web version on PubMed Central for supplementary material.

\section{ACKNOWLEDGMENTS}

This work was supported by the National Institutes of Health (R01GM125968).

\section{DREFERENCES}

(1). Filipovic RM; Zivanovic J; Alvarez B; Banerjee R Chemical biology of $\mathrm{H}_{2} \mathrm{~S}$ signaling through persulfidation. Chem. Rev 2018, 118, 1253-1337. [PubMed: 29112440]

(2). Wang R Physiological implications of hydrogen sulfide: a whiff exploration that blossomed. Physiol. Rev 2012, 92, 791-896. [PubMed: 22535897]

(3). (a)Zhao Y; Biggs TD; Xian M Hydrogen sulfide (H2S) releasing agents: chemistry and biological applications. Chem. Commun 2014, 50, 11788-11805.(b)Xu S; Hamsath A; Neill DL; Wang Y; Yang CT; Xian M Strategies for the design of donors and precursors of reactive sulfur species. Chem. - Eur. J 2019, 25, 4005-4016. [PubMed: 30372550] (c)Lin SV; Chen W; Xian M; Chang JC Chemical probes for molecular imaging and detection of hydrogen sulfide and reactive sulfur species in biological systems. Chem. Soc. Rev 2015, 44, 4596-4618. [PubMed: 25474627] (d)Zheng Y; Yu B; De La Cruz LK; Choudhury MR; Anifowose A; Wang B Toward hydrogen sulfide based therapeutics: critical drug delivery and developability issues. Med. Res. Rev 2018, 38, 57-100. [PubMed: 28240384] (e)Powell CR; Dillon KM; Matson JB A review of hydrogen sulfide (H2S) donors: chemistry and potential therapeutic applications. Biochem. Pharmacol 2018, 149, 110-123. [PubMed: 29175421] (f)Pluth MD; Bailey TS; Hammers MD; Hartle MD; Henthorn HA; Steiger AK Natural products containing hydrogen sulfide releasing moieties. Synlett 2015, 26, 2633-2643. 
(4). (a)Mousa R; Reddy PS; Metanis N Chemical protein synthesis through selenocysteine chemistry. Synlett 2017, 28, 1389-1393.(b)Metanis N; Hilvert D Natural and synthetic selenoproteins. Curr. Opin. Chem. Biol 2014, 22, 27-34. [PubMed: 25261915] (c)Steinbrenner H; Speckmann B; Klotz LO Selenoproteins: antioxidant selenoenzymes and beyond. Arch. Biochem. Biophys 2016, 595, 113-119. [PubMed: 27095226] (d)Reich HJ; Hondal RJ Why nature chose selenium. ACS Chem. Biol 2016, 11, 821-841. [PubMed: 26949981]

(5). (a)Bachrach SM; Demoin DW; Luk M; Miller JV Nucleophilic attack at selenium in diselenides and selenosulfides. A computational study. J. Phys. Chem. A 2004, 108, 4040-4046.(b)Bachrach SM; Walker CJ; Lee F; Royce S Effect of ring strain on nucleophilic substitution at selenium: A computational study of cyclic diselenides and selenyl sulfides. J. Org. Chem 2007, 72, 5174 5182. [PubMed: 17550293] (c)Benkova Z; Kóňa J; Gann G; Fabian WMF Redox chemistry of organoselenium compounds: Ab initio and density functional theory calculations on model systems for transition states and intermediates of the redox cycle of selenoenzymes. Int. J. Quantum Chem. 2002, 90, 555-565.

(6). (a)Zhao Y; Bhushan S; Yang C; Otsuka H; Stein DJ; Pacheco A; Peng B; Devarie-Baez ON; Aguilar CH; Lefer JD; Xian M Controllable hydrogen sulfide donors and their activity against myocardial ischemia-reperfusion injury. ACS Chem. Biol 2013, 8, 1283-1290. [PubMed: 23547844] (b)Park CM; Johnson BA; Duan J; Park JJ; Day JJ; Gang D; Qian WJ; Xian M 9Fluorenylmethyl (Fm) disulfides: biomimetic precursors for persulfides. Org. Lett 2016, 18, 904907. [PubMed: 26870874]

(7). Kang J; Ferrell JA; Chen W; Wang D; Xian M Cyclic acyl disulfides and acyl selenyl sulfides as the precursors for persulfides (RSSH), selenyl sulfides (RSeSH), and hydrogen sulfide (H2S). Org. Lett 2018, 20, 852-855. [PubMed: 29345467]

(8). (a)Toru T; Kanefusa T; Maekawa E A novel synthesis of thiolactones: selenothiolactonization. Tetrahedron Lett. 1986, 27, 1583-1586.(b)Toru T; Nishigaki M; Seko T; Kanefusa T; Maekawa E A convenient synthesis of S-acyl phenylselenosulfides. Synthesis 1985, 878-879.

(9). Kato S; Yasui E; Terashima K; Ishihara H; Murai T Se-Aryl alkane- or arenecarboselenothioates: synthesis and some reactions. Bull. Chem. Soc. Jpn 1988, 61, 3931-3942.

(10). Peng B; Liu C; Li Z; Day JJ; Lu Y; Lefer DJ; Xian M Slow generation of hydrogen sulfide from sulfane sulfurs and NADH models. Bioorg. Med. Chem. Lett 2017, 27, 542-545. [PubMed: 28003140]

(11). Sarma BK; Mugesh G Glutathione peroxidase (GPx)-like antioxidant activity of the organoselenium drug ebselen: unexpected complications with thiol exchange reactions. J. Am. Chem. Soc 2005, 127, 11477-11485. [PubMed: 16089478]

(12). (a)Liu H; Radford MN; Yang CT; Chen W; Xian M Inorganic hydrogen polysulfides: chemistry, chemical biology and detection. Br. J. Pharmacol 2019, 176, 616-627. [PubMed: 29669174] (b)Ono K; Akaike T; Sawa T; Kumagai Y; Wink DA; Tantillo DJ; Hobbs AJ; Nagy P; Xian M; Lin J; Fukuto JM The redox chemistry and chemical biology of $\mathrm{H}_{2} \mathrm{~S}$, hydropersulfides and derived species: implications to their possible biological activity and utility. Free Radical Biol. Med 2014, 77, 82-94. [PubMed: 25229186]

(13). Liu C; Chen W; Shi W; Peng B; Zhao Y; Ma H; Xian M Rational design and bioimaging applications of highly selective fluorescence probes for hydrogen polysulfides. J. Am. Chem. Soc 2014, 136, 7257-7260. [PubMed: 24809803]

(14). Peng B; Chen W; Liu C; Rosser WE; Pacheco A; Zhao Y; Aguilar H; Xian M Fluorescent probes based on nucleophilic substitution-cyclization for hydrogen sulfide detection and bioimaging. Chem. - Eur. J 2014, 20, 1010-1016. [PubMed: 24339269] 


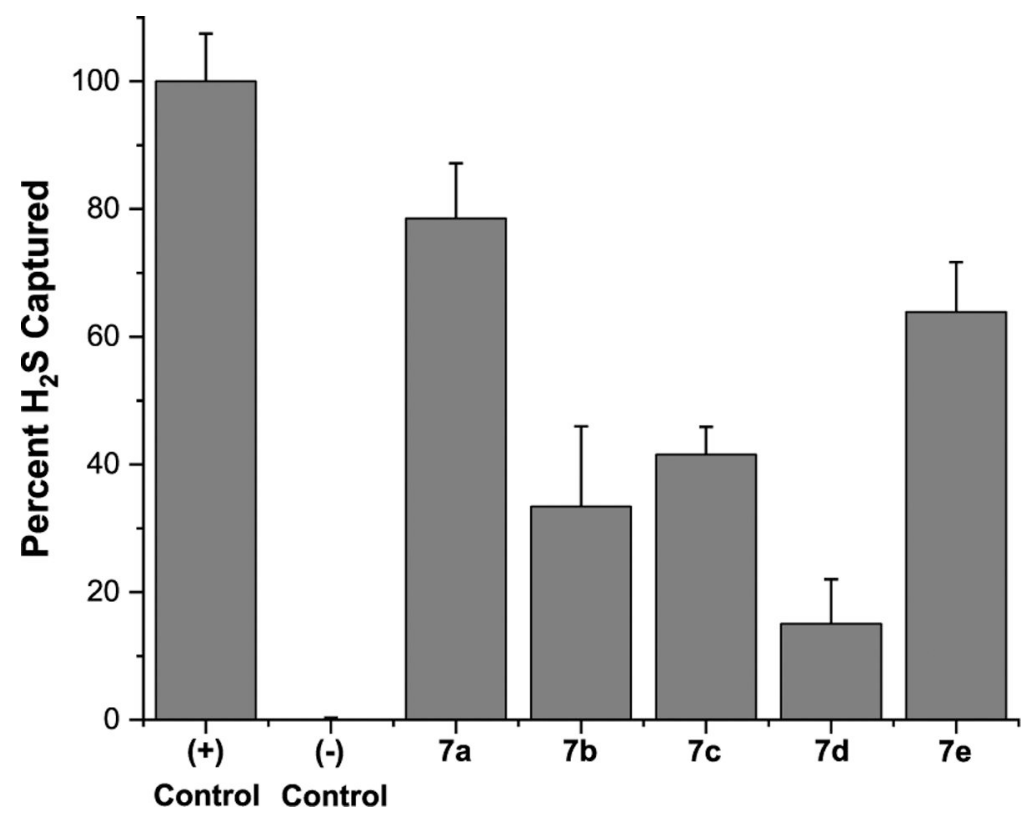

Figure 1.

Normalized $\mathrm{H}_{2} \mathrm{~S}$ production from $7 \mathrm{a}-\mathrm{e}$ measured by $\mathrm{H}_{2} \mathrm{~S}$ gas trapping assay. (+) Control: $\mathrm{Na}_{2} \mathrm{~S}(0.5 \mathrm{mM})$. (-) Control: donor only $(0.5 \mathrm{mM}) .7 \mathrm{a}-7 \mathrm{e}$ : donor $(0.5 \mathrm{mM})$ with Cys $(2.5$ $\mathrm{mM})$. 


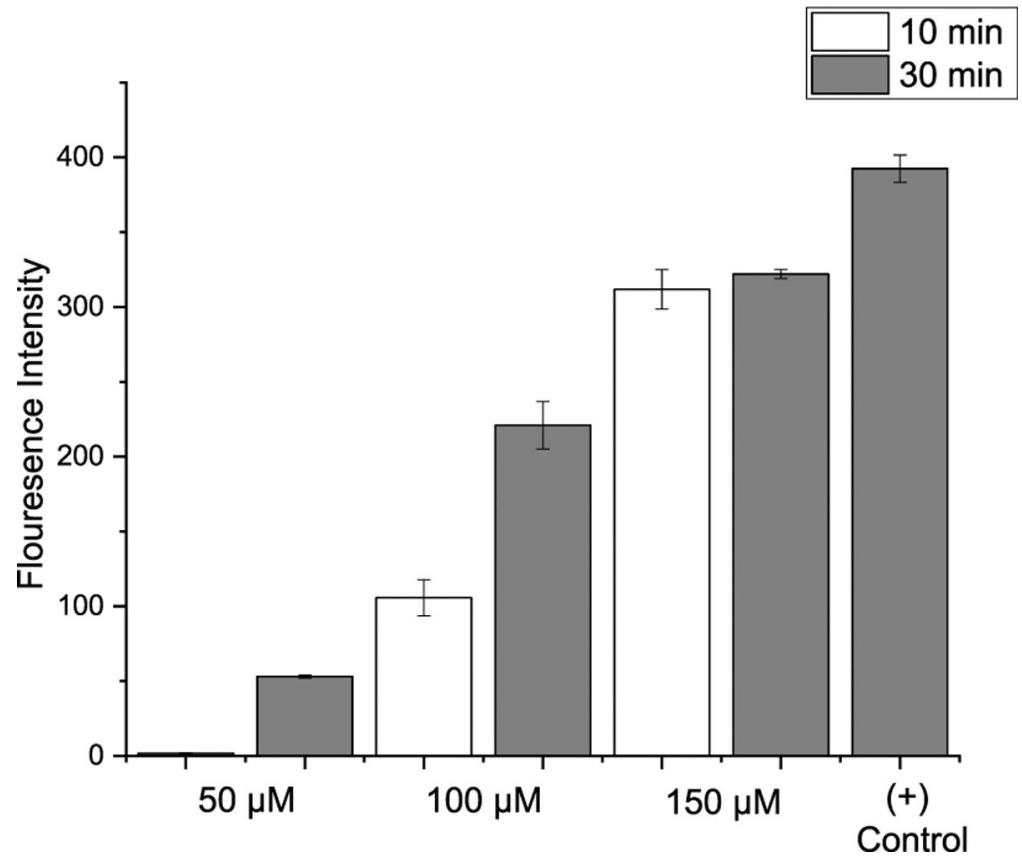

Figure 2.

Relative fluorescence intensities of DSP-3 toward the reaction between $7 \mathrm{a}$ and $\mathrm{BuNH}_{2}$. Testing solution contained DSP-3 (10 $\mu \mathrm{M}), 7 \mathrm{a}(50,100$, and $150 \mu \mathrm{M})$. (+)-Control: DSP-3 $(10 \mu M)$ and $\mathrm{Na}_{2} \mathrm{~S}_{2}(50 \mu \mathrm{M})$. 


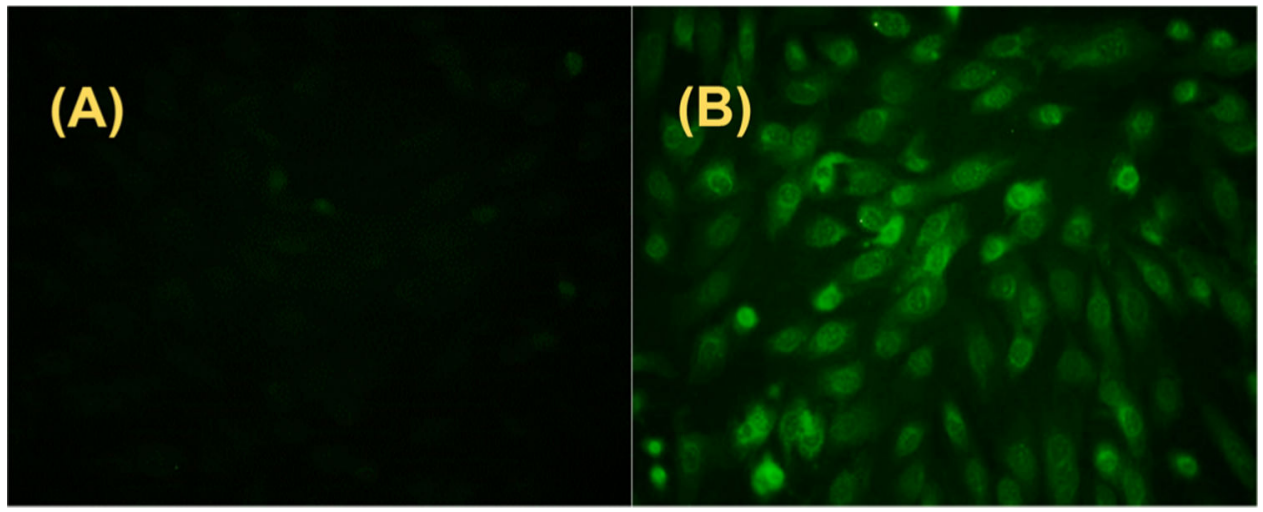

Figure 3.

Cell images of $\mathrm{H}_{2} \mathrm{~S}$ production from 7a in $\mathrm{H} 9 \mathrm{c} 2$ cells. Cells were incubated with WSP5 (10 $\mu \mathrm{M}$ ) for $30 \mathrm{~min}$ and then treated with vehicle (A) and $50 \mu \mathrm{M} \mathrm{7a}$ (B) for $60 \mathrm{~min}$. 


\section{Previous Work}
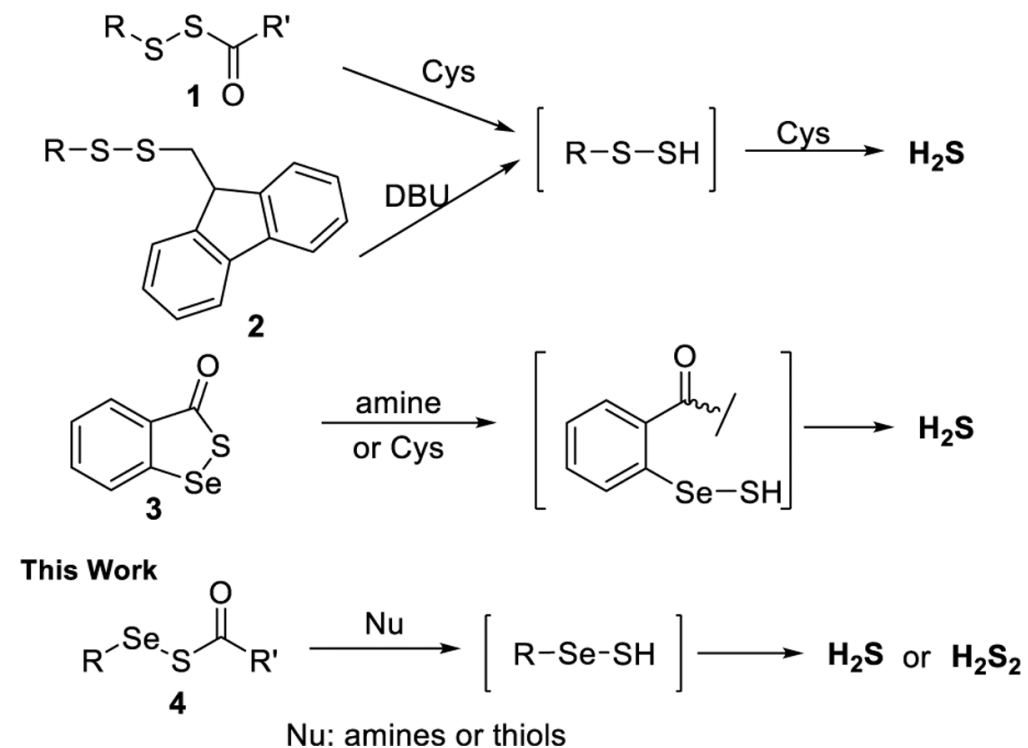

Scheme 1.

Org Lett. Author manuscript; available in PMC 2020 July 19. 


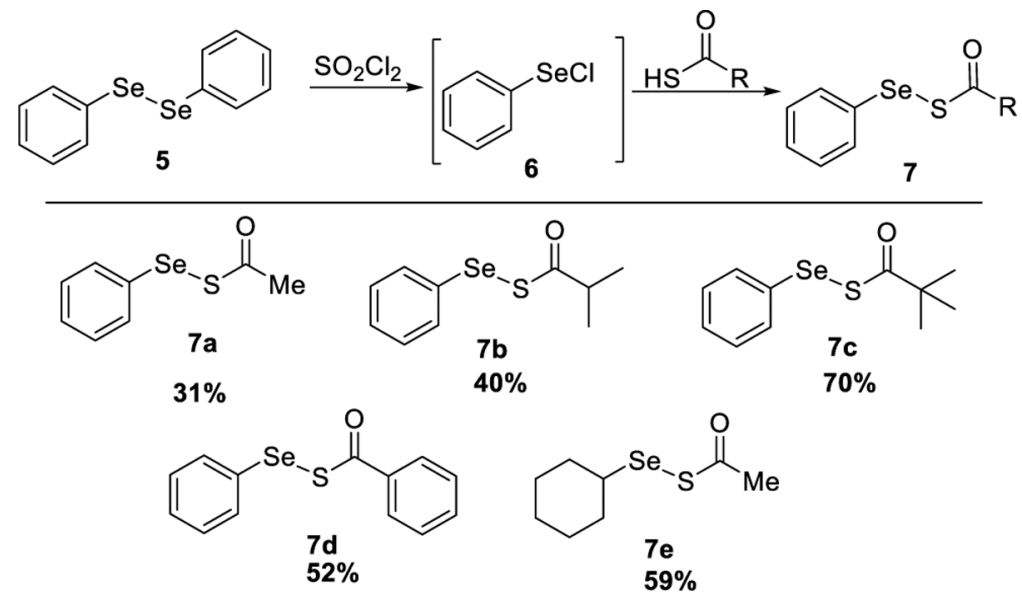

Scheme 2. 
a)<smiles>[R]C(=O)SSC([R5])=[SH](=[SH+])[Se][Se]c1ccccc1[Se][Se]c1ccccc1</smiles>

b)<smiles>[R]C(=O)OC(C)[C@@H](C)CO</smiles>

Scheme 3. 
a)

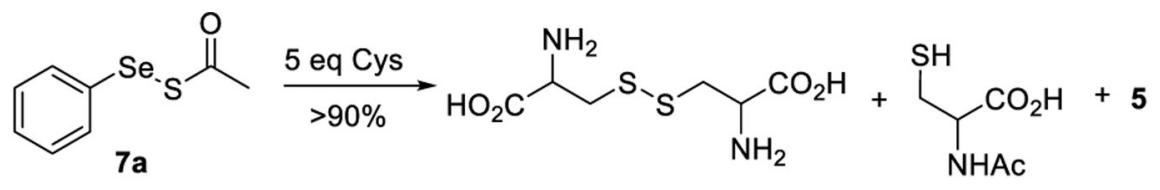

b)

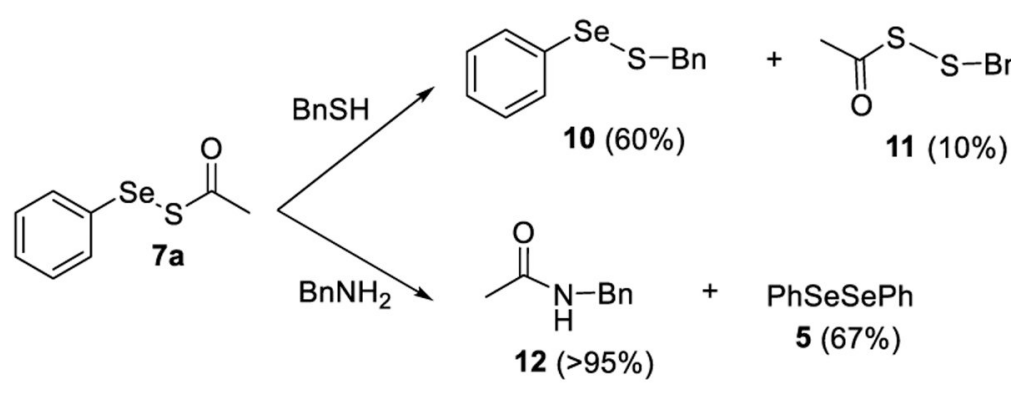

c)

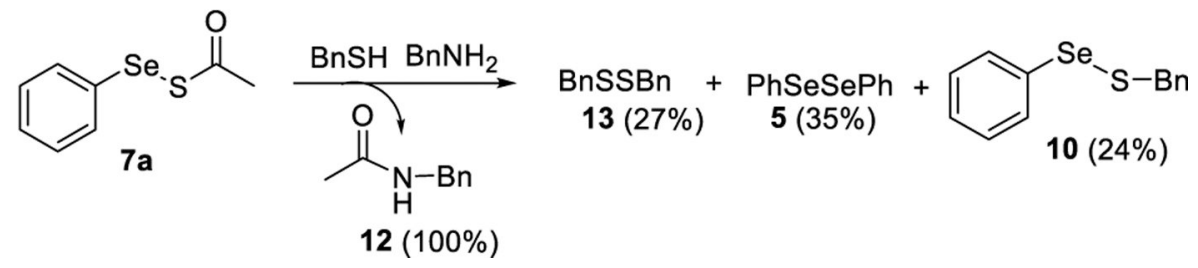

Scheme 4. 


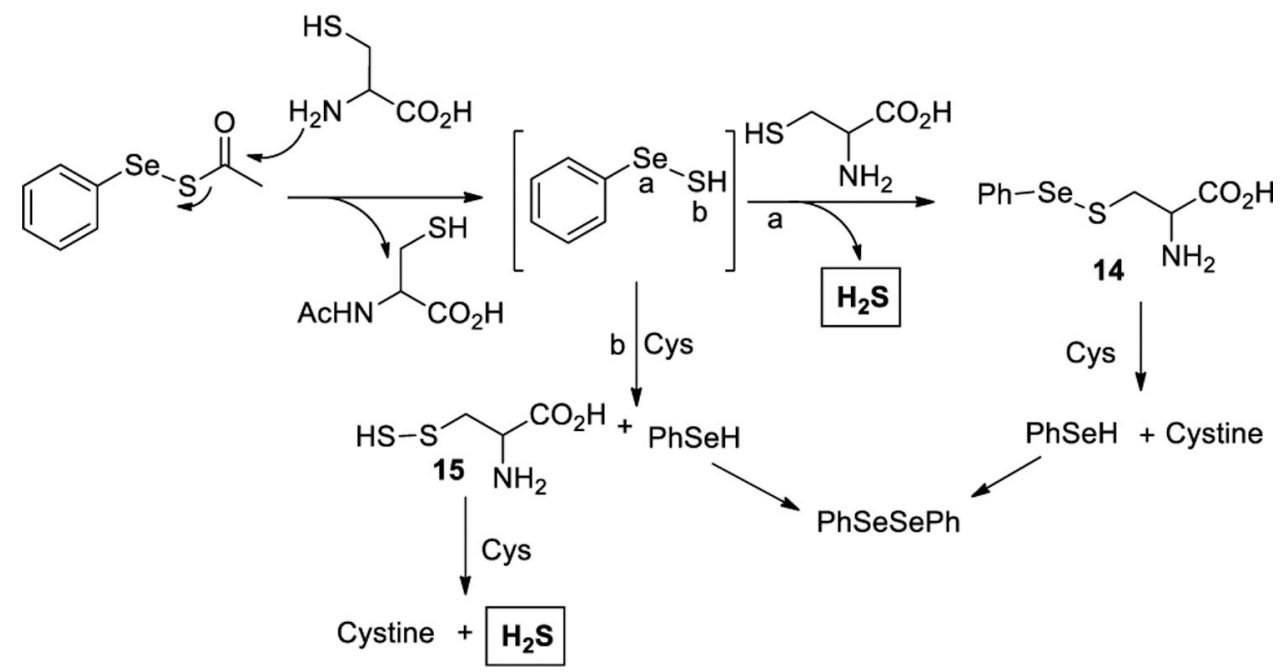

Scheme 5.

Org Lett. Author manuscript; available in PMC 2020 July 19. 


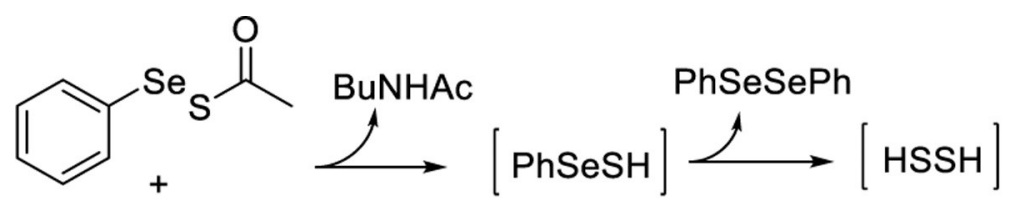

$\mathrm{BuNH}_{2}$

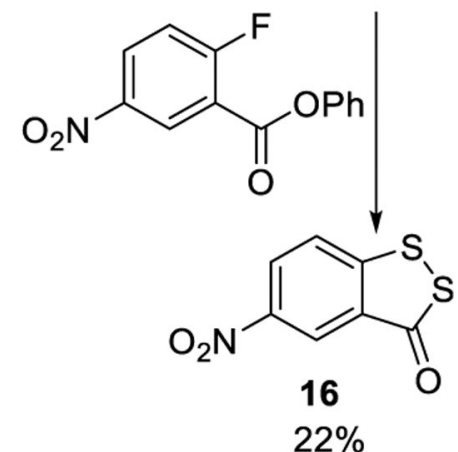

Scheme 6. 